\title{
Pediatric tumours: liver tumours
}

\author{
Alexander J Towbin \\ From International Cancer Imaging Society (ICIS) 14th Annual Teaching Course \\ Heidelberg, Germany. 9-11 October 2014
}

Pediatric liver tumors account for approximately $1 \%$ of all liver tumors and up to $2 \%$ of all pediatric malignancies $[1,2]$. While the overall incidence of liver tumors is rare, the liver remains the third most common organ of origin for solid abdominal tumors in the pediatric population [3]. The majority of pediatric liver tumors, both benign and malignant, occur (almost) exclusively in children.

Benign tumors account for one-third of all pediatric hepatic neoplasms and include infantile hepatic hemangioma, focal nodular hyperplasia, mesenchymal hamartoma, and hepatic adenoma [2-5]. Malignant neoplasms account for the remaining two-thirds of pediatric liver tumors. The most common malignancies are hepatoblastoma, hepatocellular carcinoma, fibrolamellar hepatocellular carcinoma, undifferentiated embryonal sarcoma, and biliary rhabdomyosarcoma [4-6]. While the majority of these tumors are unique to children, focal nodular hyperplasia, hepatocellular adenomas, and hepatocellular carcinoma have counterparts in adults. The presentation, risk factors, and imaging appearance of these overlapping tumors differs in the pediatric population as compared to adults $[7,8]$.

Even though there are a number of different liver tumors, the radiologist can often make a confident diagnosis based on the clinical information and imaging appearance of the mass $[9,10]$. The purpose of this lecture is to describe the imaging work-up for pediatric liver masses and then discuss each tumor, focusing on its unique clinical and imaging features.

\section{Published: 9 October 2014}

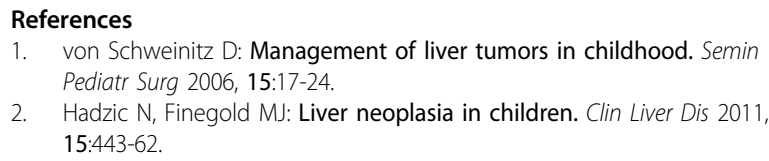

2. Hadzic N, Finegold MJ: Liver neoplasia in children. Clin Liver Dis 2011 15:443-62

Cincinnati Children's Hospital, Department of Radiology, Cincinnati, OH 45229, USA

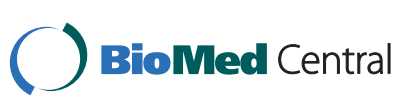

(c) 2014 Towbin; licensee BioMed Central Ltd. This is an Open Access article distributed under the terms of the Creative Commons Attribution License (http://creativecommons.org/licenses/by/4.0), which permits unrestricted use, distribution, and reproduction in any medium, provided the original work is properly cited. The Creative Commons Public Domain Dedication waiver (http:// creativecommons.org/publicdomain/zero/1.0/) applies to the data made available in this article, unless otherwise stated.
3. Kochin IN, Miloh TA, Arnon R, lyer KR, Suchy FJ, Kerkar N: Benign liver masses and lesions in children: 53 cases over 12 years. Isr Med Assoc J 2011, 13:542-7.

4. Chung EM, Cube R, Lewis RB, Conran RM: From the archives of the AFIP: Pediatric liver masses: radiologic-pathologic correlation part 1. Benign tumors. Radiographics 2010, 30:801-26.

5. Meyers RL: Tumors of the liver in children. Surg Oncol 2007, 16:195-203.

6. Chung EM, Lattin GE Jr, Cube R, Lewis RB, Marichal-Hernández C, Shawhan R, Conran RM: From the archives of the AFIP: Pediatric liver masses: radiologic-pathologic correlation. Part 2. Malignant tumors. Radiographics 2011, 31:483-507.

7. Towbin AJ, Luo GG, Yin H, Mo JQ: Focal nodular hyperplasia in children, adolescents, and young adults. Pediatr Radiol 2011, 41:341-9.

8. Smith EA, Salisbury S, Martin R, Towbin AJ: Incidence and etiology of new liver lesions in pediatric patients previously treated for malignancy. AJR Am J Roentgenol 2012, 199:186-91.

9. Meyers AB, Towbin AJ, Serai S, Geller Jl, Podberesky DJ: Characterization of pediatric liver lesions with gadoxetate disodium. Pediatr Radiol 2011, 41:1183-97.

10. Meyers AB, Towbin AJ, Geller J, Podberesky DJ: Hepatoblastoma imaging with gadoxetate disodium-enhanced MRI-typical, atypical, pre- and post-treatment evaluation. Pediatr Radiol 2012, 42:859-66.

doi:10.1186/1470-7330-14-S1-016

Cite this article as: Towbin: Pediatric tumours: liver tumours. Cancer Imaging 2014 14(Suppl 1):016.

\section{Submit your next manuscript to BioMed Central and take full advantage of:}

- Convenient online submission

- Thorough peer review

- No space constraints or color figure charges

- Immediate publication on acceptance

- Inclusion in PubMed, CAS, Scopus and Google Scholar

- Research which is freely available for redistribution 